\title{
Water Quality Assessment Klang River Water Treatment Plants
}

\author{
HA Mohiyaden ${ }^{1}$ * LM Sidek ${ }^{2}$, G Hayder ${ }^{3}$, MN Noh ${ }^{4}$ \\ ${ }^{1}$ Sustainable Technology and Environment Group, Institute of Energy Infrastructure, Universiti Tenaga Nasional, Jalan IKRAM- \\ UNITEN, 43000 Kajang Selangor \\ ${ }^{2}$ Department of Civil Engineering, Universiti Tenaga Nasional, Jalan IKRAM-UNITEN, 43000 Kajang Selangor \\ ${ }^{3}$ Malaysia Department of Irrigation and Drainage, Jalan Sultan Salahuddin, 50480 Kuala Lumpur, Wilayah Persekutuan Kuala Lumpur, \\ Malaysia \\ *Corresponding author E-mail: hairunaishah@gmail.com
}

\begin{abstract}
The quality of Klang river water is deteriorating dramatically since it is in urban places every day and become one of the major problems. Therefore, the Malaysian government had initiated one river cleaning project named River of Life (ROL) project. This project is for rehabilitating and restoring the Klang river. A series of river water treatment plant (RWTP)s have been operated in Klang river catchment since 2014. Six RWTPs station has been monitored up to eight stations until presents. Eight parameters consisting of physio-chemical types and biological types have been recorded. RWTP effluent discharges are targeted to achieve Malaysia Interim National Water Quality Standard (INWQS) under Class II B. Since previous RWTP performance only emphasized on local river pollutants and certain conditions, this paper will investigate the effectiveness of full-scale RWTP unit process for river condition. Water quality assessment are involved which are consist of effluent water quality monitoring and pollutant removal efficiency. Most of the major pollutants able to be reduced by more than $50 \%$ reduction. Although BOD and AN still not able to achieve standard range gazetted by INWQS Class IIB, there is an improvement of river water quality at Klang River by using IFAS technology adopted in the RWTP system.
\end{abstract}

Keywords: MBBR; IFAS; River; Water Quality

\section{Introduction}

In the last few decades river management and restoration play an important role in the environment. Therefore, various researchers are conducted in this applied research field [1]-[3]. In the fields of research a major area is improving the water quality of the river [4], [5]. For example, the quality of Klang river water is deteriorating intensely since it is in urban places and become one of the major problems. The causes are both natural (e.g. changes in precipitation; flood; erosion;) and anthropogenic (e.g. urban, industrial and human activities) reasons for this problem. The effective way of river cleaning requires identification and quantification of both natural and anthropogenic influences and increased understanding of contaminant sources, which become a key factor for regarding planning, mitigation and cleanup processes [6]-[8].

The effective way of river cleaning requires identification and quantification of both natural and anthropogenic influences and increased understanding of contaminant sources, which become a key factor for regarding planning, mitigation and cleanup processes. The efforts to develop innovative attempts have seen be made to decontaminate rivers water directly and continuously. Therefore, the Malaysian government had initiated one river cleaning project; River of Life (ROL) project. This project is for rehabilitating and restoring the Klang river. From twelve (12) key activities have been proposed under river cleaning task force, a new technology called river water treatment plant (RWTP) had been introduced to purify the Klang river water[9]. Likely in Korea, their RWTP process is consist of gravel and artificial media which contain high surface area in contact with the surface organic substance. RWTP in Yangjae river able to remove $60 \%$ of Biochemical Oxy- gen Demand, $70 \%$ of Total Suspended Solid, 36\% of Total Phosphorus.[10]

There are many water treatment plant technologies, either from laboratory or pilot-scale studies were known to successfully treat river water to certain degree of removal efficiency. However, continuous urban river pollution issues in Malaysia have urged more studies to be conducted to get intuition into new technologies approaches especially on RWTP. Determination of issues and problem facing by this new technology are very important besides there are no studies have been conducted to assess the effectiveness of this technologies. Plus, previous RWTP performance only emphasized on local river pollutants and certain conditions. This research work is implemented to investigate the effectiveness of unit processes combined in full-scale RWTP for Klang river condition.

\section{Methodology}

A series of RWTPs have been in the operation in Klang river catchment since 2014. The detailed description and location of RWTP have been described in the previous publication.[11] Fourteen (14) unit of RWTPs apply biological water treatment as similar has been incorporated Integrated Fixed Activated Sludge System (IFAS) and Moving Bed Biological Reactor (MBBR) as mention in previous publications [12]-[15]. The approaches included preliminary treatments (mixing and grit removal tank), secondary biological treatments (oxidation tank with fixed carrier), and clarifier.

The processes involved in Klang RWTP are depicted as below and Table 1: 
Inlet structure $\rightarrow$ Mixing tanks $\rightarrow$ Grit Removal $\rightarrow$ Oxidation with alternate fixed carrier (12 units) $\rightarrow$ Clarifier $\rightarrow$ Outlet structure.

Water quality assessment consist of two types of activities:

RWTP effluent water quality monitoring

Pollutant removal efficiency

Table 1: RWTP Operation Information

\begin{tabular}{|l|l|}
\hline Operation & \pm 360 days per year \\
\hline Sludge Collection & Yes \\
\hline Sludge Recycle & No \\
\hline Design Discharge $\left(\mathrm{Q}_{\text {design }}\right)$ & $0.01 \mathrm{~m}^{3} / \mathrm{s}$ \\
\hline Hydraulic Retention Time & $2 \mathrm{hr}$ \\
\hline \multirow{2}{*}{ Nos Oxidation Tank } & 8 unit in total \\
\cline { 2 - 2 } & 4 units with carriers \\
\hline Types of Biological Process & $\begin{array}{l}\text { Attached growth process with } \\
\text { fixed-carriers (IFAS) }\end{array}$ \\
\hline
\end{tabular}

\subsection{Water Quality Monitoring}

Since 2014, 6 RWTPs station has been monitored up to 8 stations until presents. 8 parameters consisting of physio-chemical types and biological types have been recorded at the inlet and outlet point each station for monitoring the performance of RWTPs as follows;

1. Dissolved Oxygen (DO)

2. $\mathrm{pH}$

3. Temperature

4. Chemical Oxygen Demand (COD)

5. Biochemical Oxygen Demand (BOD) at $20^{\circ} \mathrm{C}$

6. Ammonia Nitrogen (AN)

7. Total Suspended Solid (TSS)

8. Escherichia-coli (E. coli)

RWTP effluent discharges are targeted to achieve Malaysia Interim National Water Quality Standard (INWQS) under Class II B which categorized as clean and suitable for recreational purposes

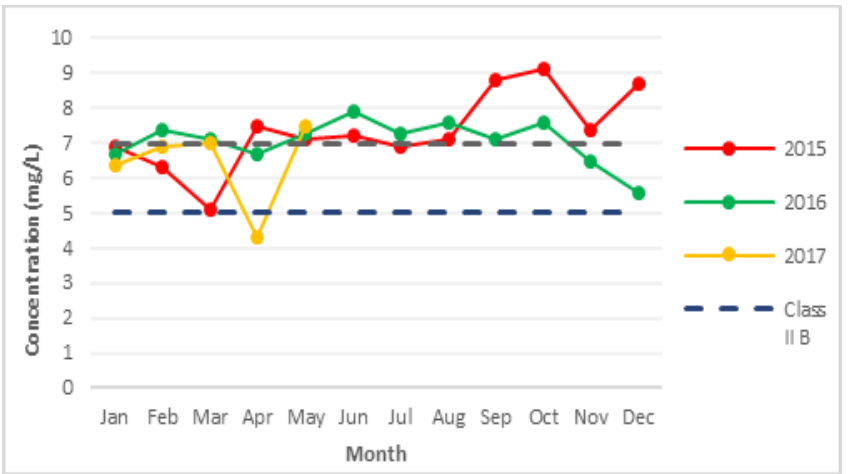

Fig. 1: Trend in DO data at RWTP outlet point from Jan 2015 to May 2016

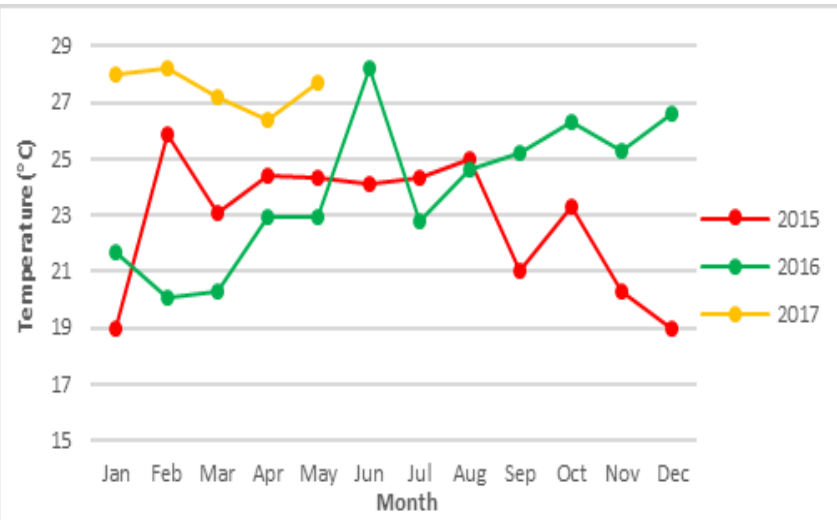

Fig. 3: Trend in temperature at Klang river RWTP outlet point from Jan 2015 to May 2016 involving body contact. This target is initially has been set up as one of the main objectives in ROL Project. One of the RWTP has been analyzed situated at Klang River $\left(3^{\circ} 11^{\prime} 00.1 " \mathrm{~N}\right.$ $\left.101^{\circ} 45^{\prime} 37.0^{\prime \prime E}\right)$. Sampling duration is analyzed from early 2015 until middle 2017. Each effluent result is compared with INWQS Class II B limit.

\subsection{Constituent Removal Efficiency}

The removal efficiency for MBBR and IFAS, R (\%) was determined by using the equation below:

$R=\frac{c_{\mathrm{s}}-C_{\mathrm{E}}}{r} \times 100 \%$

where $\mathrm{C}_{0}$ and $\mathrm{C}_{\mathrm{t}}(\mathrm{mg} / \mathrm{L})$ are the pollutant liquid-phase concentrations at initial and time $\mathrm{t}$ (day), respectively [16]. Then all the results will be tabulated, and graph or charts were built. All charts were developed using Microsoft Excel except for Removal Efficiency using Statistical Package Social Science (SPSS) programme version 11.0

\section{Result and Discussion}

The results obtained from data collected from the monthly grab sampling at Klang RWTP. Water quality monitoring at the effluent point and pollutant removal efficiency for each RWTP station will be discussed.

\subsection{Effluent Water Quality}

Effluent monitoring for every pollutant is plotted as shown in Fig 1 to Fig 8 .

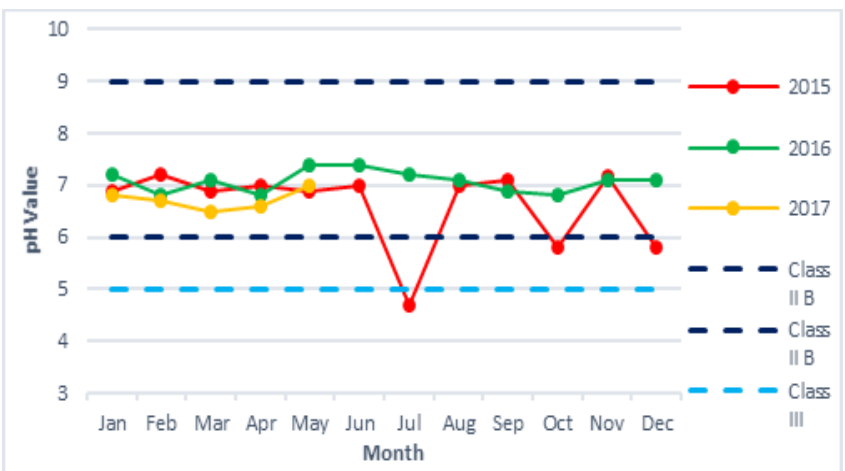

Fig. 2: Trend in pH data at RWTP outlet point from Jan 2015 to May 2016

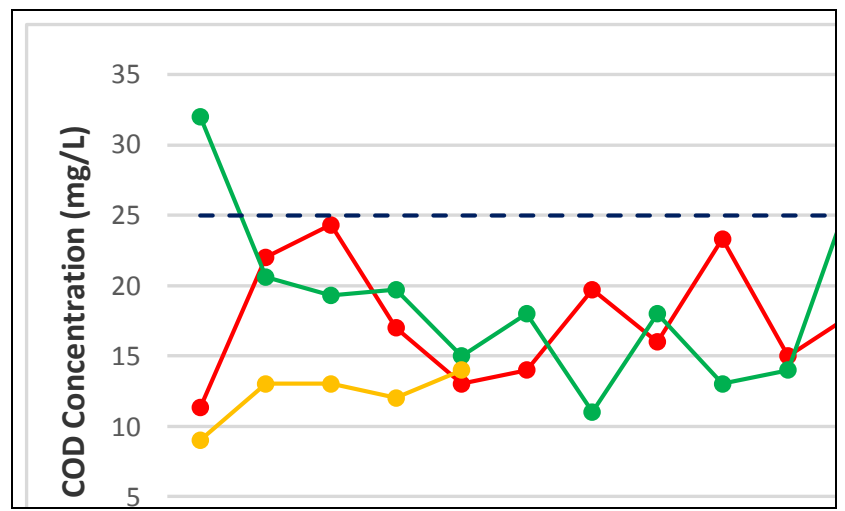

Fig. 4: Trend in COD at Klang river RWTP outlet point from Jan 2015 to May 2016 


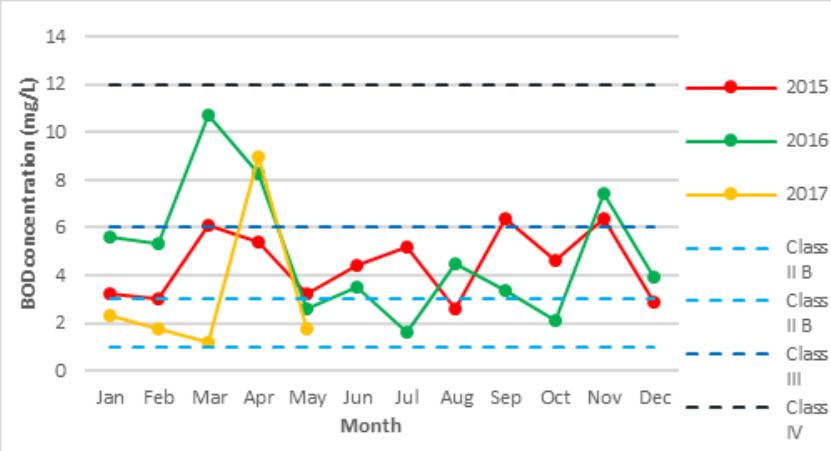

Fig. 5: Trend in BOD at Klang river RWTP outlet point from Jan 2015 to May 2016

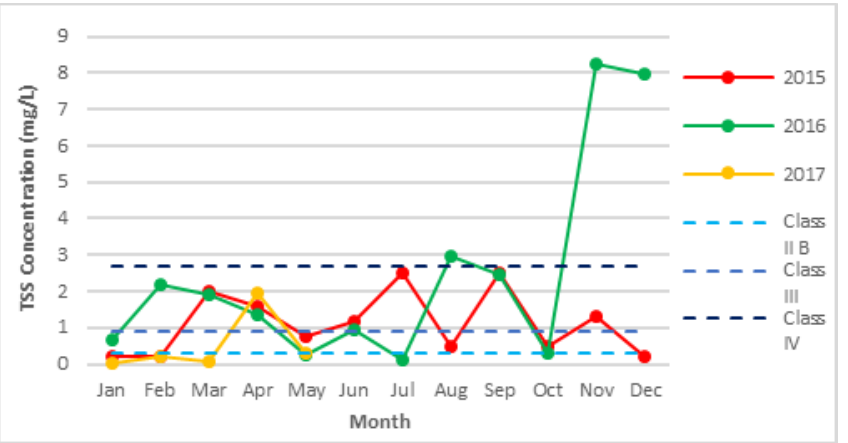

Fig. 7: Trend in AN at Klang river RWTP outlet point from Jan 2015 to May 2016

Malaysia experienced hot season and received a low amount of rainfall from the month of March to May. This matter could be resulting Klang river water level is decreasing and tends to reduce DO concentration as have seen in the Mar-2015 and Apr-2017 trends in Fig. 1. However, most of the DO level is more than 4.00 $\mathrm{mg} / \mathrm{L}$ due to enough supply from the aeration process in the RWTP biological tank.

$\mathrm{pH}$ is crucial for monitoring the purification activities in the surface water. Hydrolysis process of organic compounds by biological degradation and rate of collision of sediment aggregated process is highly dependent on $\mathrm{pH}[17]-[19]$.Most of the $\mathrm{pH}$ result at the outlet point is considerable achieve the target Class II B except for July 2015 (Class III) as shown in Fig 2.

The temperature of effluent varies from 19.0 to $28.5^{\circ} \mathrm{C}$ as depicted in Fig 3. The effluent COD for most of the month is according to the standard range gazette by INWQS Class IIB (Fig 4) which is permitted to be within COD 10-205 $\mathrm{mg} / \mathrm{L}[20]$. COD can be useful in pinpointing toxic condition and presence of biological resistant substances. Besides, MBBR and IFAS system which are adopted in RWTP are proven to improve the amount of COD up to $95 \%$ [21], [22].

There are $66 \%$ of total effluents BOD are not achieved to the range published by INWQS Class IIB (Fig 5). These are due to the high concentration of organic matter which has been reported in Klang river ensuing by high amount BOD [23]. As shown in Fig 6, TSS able to be reduced by MBBR and IFAS up to Class I mainly clarifier process [24]. Most of the effluents AN are not achieved to the range gazette by INWQS Class IIB as shown in Fig 7. Most of the MBBR and IFAS with nitrification control process able to reduce the desired amount of AN and Total Nitrogen and its byproducts[25]. The effluent E. coli as shown in Fig 8 shows the significant reduction trend from the year 2015 to the year 2016.

\subsection{Pollutant Removal Efficiency}

From the Table 1 and Fig 9, COD removal rate is mostly 55\%, BOD is $62 \%$, TSS is $67 \%$, AN $80 \%$ and E. coli reducing the highest rate which is $95 \%$.

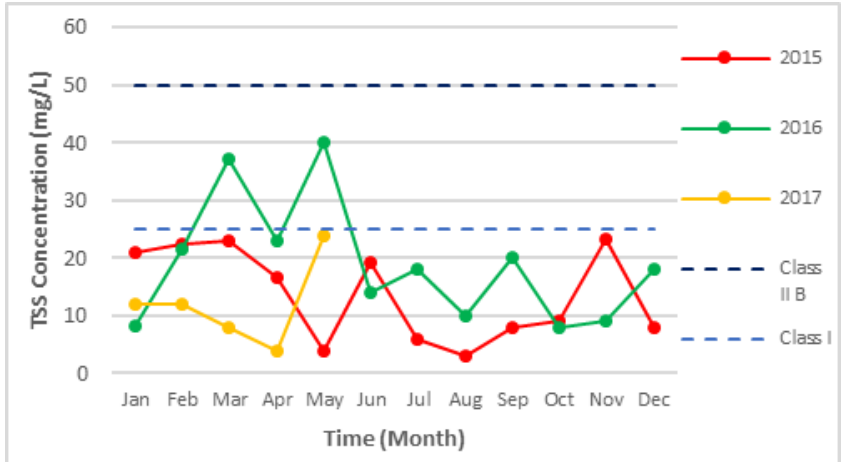

Fig. 6: Trend in TSS at Klang river RWTP outlet point from Jan 2015 to May 2016

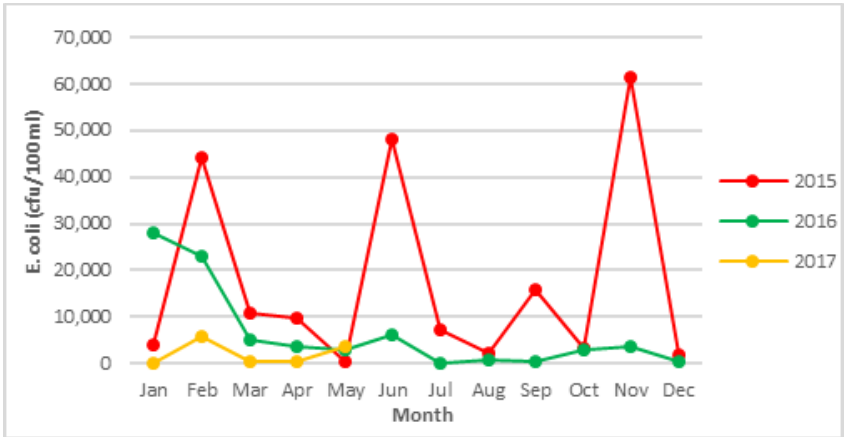

Fig. 8: Trend in E. coli at Klang river RWTP outlet point from Jan 2015 to May 2016

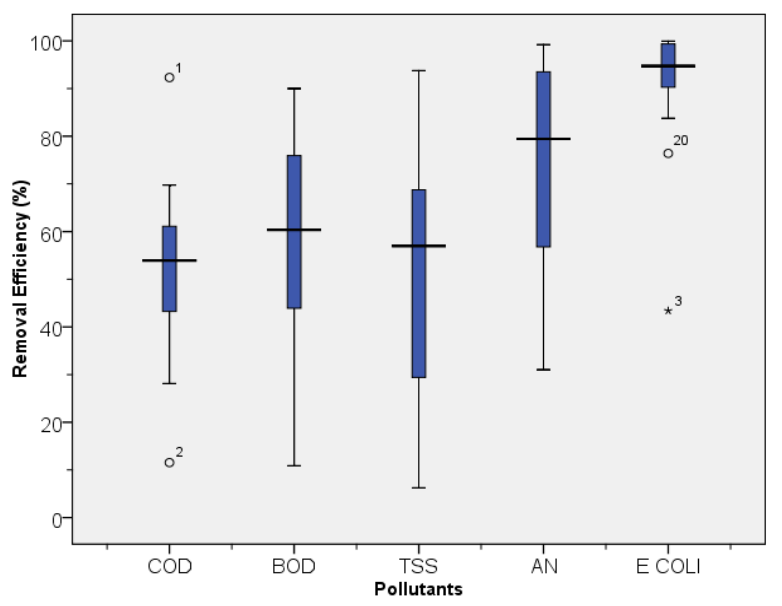

Fig. 9: Removal Efficiency for Klang RWTP

Table 1: Descriptive Analysis for Removal Efficiency

\begin{tabular}{|c|c|c|c|c|c|}
\hline & COD & BOD & TSS & AN & E COLI \\
\hline Mean & 53.256 & 58.261 & 52.551 & 74.258 & 92.088 \\
\hline Median & 55.000 & 61.855 & 56.980 & 79.960 & 95.460 \\
\hline Mode & 31.25 & 25.00 & 66.67 & $31.02 \mathrm{a}$ & $90.27 \mathrm{a}$ \\
\hline Std. Deviation & $1.544 \mathrm{E} 1$ & $2.1659 \mathrm{E} 1$ & $2.4647 \mathrm{E} 1$ & $2.0829 \mathrm{E} 1$ & $1.0785 \mathrm{E} 1$ \\
\hline Minimum & 11.54 & 10.87 & 6.25 & 31.02 & 43.40 \\
\hline Maximum & 92.31 & 93.55 & 93.75 & 99.21 & 99.97 \\
\hline
\end{tabular}

Despite of E-Coli, RWTP Klang able to reduce tremendous amount of AN $(80 \pm 2.08 \%)$ although the RWTP unit system are prior for organic substance removal. This is due to IFAS system are consider as hybrid performance which are consist of suspended and attached growth system.[26], [27]

Multiple previous studies have been conducted for nitrification process for removal $\mathrm{AN}$ and its group substances; Nitrite and Nitrate.[28] Nitrification process able to specific reduce ammonia content by Ammonia oxidizing bacteria (AOB) and Anaerobic Ammonium Oxidation (Annamox).[29], [30] In pilot case study, 
from a retrofit Sequencing Batch Reactor (SBR) to IFAS was conducted by Zhao 2018, the IFAS unit able to reduce $90 \%$ of CBOD and $96 \%$ of AN.[31]. It is proved that nitrification process are occurs in IFAS oxidation tank during shutdown of alternate aeration supply in every 30 minutes (average) for substrate utilization by Annamox bacteria. Most of the major pollutants able to be reduced by more than $50 \%$ reduction as depicted in Fig 9 . Hence, there is an improvement of river water quality at Klang River by using RWTP technology.

\section{Conclusion}

Most of the major pollutants able to be reduced by more than $50 \%$ reduction. Although BOD and AN still not able to achieve standard range gazetted by INWQS Class IIB, there is an improvement of river water quality at Klang River by using IFAS technology adopted in the RWTP system.

\section{Acknowledgement}

The authors acknowledge the UNITEN R\&D Sdn Bhd Research Contract (U-EN-CR-17-21) from the Malaysia Department of Irrigation and Drainage (DID) for providing financial support for this research project. A part of the instrumentation used in this study was supported by Environmental Engineering Laboratory, Sustainable Technology and Environment Research Group (STEG), Universiti Tenaga Nasional (UNITEN).

\section{References}

[1] I. A. R. Al-Ani, L. M. Sidek, M. M. N. Desa, and N. E. Ahmad Basri, "Knowledge-based expert system for stormwater management in Malaysia," J. Environ. Sci. Technol., vol. 5, no. 5, (2012), pp. 381-388.

[2] N. Othman, N. E. A. Basri, M. N. M. Yunus, L. M. Sidek, and N. A Othman, "Potential of electronic plastic waste as a source of raw material and energy recovery | Potensi Sisa Plastik Elektronik sebagai Sumber kepada Penghasilan Tenaga dan Bahan Mentah,' Sains Malaysiana, vol. 38, no. 5, (2009), pp. 707-715.

[3] K. R. Ayub, L. M. Sidek, A. Ainan, N. A. Zakaria, A. A. Ghani, and A. Rozi, "Storm water treatment using bio-ecological drainage system,” Int. J. River Basin Manag., vol. 3, no. 3, (2005), pp. 215 221 .

[4] M. S. Lariyah et al., "Application of Moving Bed Biofilm Reactor (MBBR) and Integrated Fixed Activated Sludge (IFAS) for Biological River Water Purification System: A Short Review," IOP Conf. Ser. Earth Environ. Sci., (2016).

[5] M. Jajarmizadeh, L. M. Sidek, M. Mirzai, S. Alaghmand, S. Harun, and M. R. Majid, "Prediction of Surface Flow by Forcing of Climate Forecast System Reanalysis Data," Water Resour. Manag., vol. 30, no. 8, (2016), pp. 2627-2640.

[6] K. H. Kok, L. M. Sidek, M. R. Z. Abidin, H. Basri, Z. C. Muda, and $\mathrm{S}$. Beddu, "Evaluation of green roof as green technology for urban stormwater quantity and quality controls," IOP Conf. Ser. Earth Environ. Sci., vol. 16, no. February, (2013) p. 012045.

[7] C. M. Fai et al., "Hydrological performance of native plant species within extensive green roof system in Malaysia," ARPN J. Eng. Appl. Sci., vol. 10, no. 15, (2015), pp. 6419-6423.

[8] M. F. Chow, M. F. Abu Bakar, L. M. Sidek, and H. Basri, "Effects of substrate types on runoff retention performance within the extensive green roofs,” J. Eng. Appl. Sci., vol. 12, no. 21, (2017), pp. 5379-5383.

[9] D. of I. and D. M. DID, "Technical Talk on Greater KL / KV - The River of Life Project," The Institution of Engineer Malaysia, no. May, Kuala Lumpur, (2012), pp. 36-37.

[10] MJ, "A Study on the Oxidation of Gravel Contact, for water purification on Yangjae Stream," Naver, (2014). [Online]. Available:

https://m.blog.naver.com/PostView.nhn?blogId=alswjd6253\&logN $\mathrm{o}=208871252$ \&proxyReferer $=$. [Accessed: 20-Jun-2018].

[11] H. Mohiyaden, L. Sidek, S. Shahrunizam, and G. Hayder, "Field Testing and Performance Evaluation of River Water Treatment Plants," in The European Proceeding of Social \& Behavioural
Sciences EpSBS, Volume XLIV-IEBMC 2017, (2018), p. 960-970.

[12] G. Hayder, L. M. L. M. Sidek, H. A. H. A. Mohiyaden, H. Basri, and C. Ming Fai, "Comparison of various types of biomedia in river water treatment using attached growth activated sludge process," Int. J. River Basin Manag., Jul. (2015), pp. 1-6,

[13] L. Sidek, H. A. Mohiyaden, L. K. Lee, and K. Y. Foo, "Potential of engineered biomedia for the innovative purification of contaminated river water," Desalin. Water Treat., (2016), pp. 1-12.

[14] L. Mohd Sidek et al., "Experimental Comparison between Moving Bed Biofilm Reactor (MBBR) and Conventional Activated Sludge (CAS) for River Purification Treatment Plant," Adv. Mater. Res., vol. 1113, (2015), pp. 806-811.

[15] H. A. H. A. Mohiyaden et al., "Conventional methods and emerging technologies for urban river water purification plant: A short review," ARPN J. Eng. Appl. Sci., vol. 11, no. 4, (2016), pp. 2547-2556.

[16] H. A. Mohiyaden et al., "Biological Carrier Performance Evaluation for Artificial River Purification," 13th Int. Conf. Urban Drainage, Sarawak, Malaysia, (2014), pp. 7-12.

[17] H. Imran, "Performance evaluation of biosimulator for treating domestic wastewater using activated sludge treatment system," J. Appl. Sci. Environ. Manag., vol. 2, no. 051, (2007), pp. 126-139.

[18] A. S. Sutar, R. K. Mulla, and A. C. Ranveer, "Effluent Treatment Plant of Dairy Wastewater - A Performance Evaluation," no. November 2015, (2015), pp. 837-840.

[19] A. M. Sheela, J. Letha, S. Joseph, M. Chacko, S. P. Sanal kumar, and J. Thomas, "Water quality assessment of a tropical coastal lake system using multivariate cluster, principal component and factor analysis," Lakes Reserv. Res. Manag., vol. 17, no. 2, (2012), pp. 143-159.

[20] M. of N. R. and E. DOE, "Malaysian Environment Quality Report 2016," Putrajaya, Kuala Lumpur, (2016).

[21] G. Mannina et al., "Bacterial community structure and removal performances in IFAS-MBRs: A pilot plant case study," J. Environ. Manage., vol. 198, (2017) pp. 122-131.

[22] D. Rosso et al., "Oxygen transfer and uptake, nutrient removal, and energy footprint of parallel full-scale IFAS and activated sludge processes," Water Res., vol. 45, no. 18, (2011), pp. 5987-5996.

[23] C. L. Chan, M. K. Zalifah, and A. S. Norrakiah, "Microbiological and Physicochemical Quality of Drinking Water," Malaysian J. Anal. Sci., vol. 11, no. 2, (2007), pp. 414-420.

[24] P. Moretti, J.-M. Choubert, J.-P. Canler, P. Buffière, O. Pétrimaux, and P. Lessard, "Dynamic modeling of nitrogen removal for a three-stage integrated fixed-film activated sludge process treating municipal wastewater," Bioprocess Biosyst. Eng., (2017), vol. 0, no. 0123456789.

[25] U. Barry, J. Choubert, J. Canler, A. Héduit, and P. Lessard, “A onedimensional moving bed bioreactor model for nitrification of municipal wastewaters," BIOPROCESS Biosyst. Eng., no. 2006, (2007), pp. 1-9.

[26] H. Eslami, M. H. Ehrampoush, H. Falahzadeh, and P. T. Hematabadi, "Biodegradation and nutrients removal from greywater by an integrated fixed - film activated sludge ( IFAS ) in different organic loadings rates," AMB Express, (2018).

[27] B. Li, Y. Qiu, C. Zhang, L. Chen, and H. Shi, "Understanding biofilm diffusion profiles and microbial activities to optimize integrated fixed-film activated sludge process," Chem. Eng. J., vol. 302, no. September 2017, (2016), pp. 269-277.

[28] C. S. Butler and J. P. Boltz, "Biofilm Processes and Control in Water and Wastewater Treatment," Compr. Water Qual. Purif., no. December 2014, (2014), pp. 90-107.

[29] G. Mannina et al., "Bacterial community structure and removal performances in IFAS-MBRs: A pilot plant case study,” J. Environ. Manage., vol. 198, no. August, (2017), pp. 122-131.

[30] C. Huang, Y. Shi, J. Xue, Y. Zhang, M. Gamal El-Din, and Y. Liu, "Comparison of biomass from integrated fixed-film activated sludge (IFAS), moving bed biofilm reactor (MBBR) and membrane bioreactor (MBR) treating recalcitrant organics: Importance of attached biomass," J. Hazard. Mater., vol. 326,(2017), pp. 120-129.

[31] R. Zhao, H. W. Zhao, R. Dimassimo, and G. Xu, "Pilot Scale Study of Sequencing Batch Reactor (SBR) Retrofit with Integrated Fixed Film Activated Sludge (IFAS): Nitrogen Removal and Design Consideration," Environ. Sci. Water Res. Technol., (2018). 